\title{
Makna Pengobatan Tradisional Badewah Suku Dayak Bagi Masyarakat Muslim di Kalimantan Tengah
}

\author{
Asmawati \\ IAIN Palangka Raya \\ asmawatiaqilaa6@gmail.com \\ Zaenap Hartati \\ IAIN Palangka Raya \\ zainap.hartati@iain-palangkaraya.ac.id \\ Emawati \\ IAIN Palangka Raya \\ emasetyo@yahoo.com
}

\begin{abstract}
The development of science and technology can not replace the meaning of traditional medicine. Some people choose traditional medicine that have less side effects, is also related to the community's beliefs. Thus, the present study will basically try to answer such questions as: What is a badewab? How is the meaning of badewah for the Moslems communty of Muara Teweh? The study was conducted in North Barito District, Central Kalimantan. The research data consists of language, action, experience and history. The result of research as: badewah is a traditional treatment by praying to the God for healhty. Badewah treats the irrational disease and eternal disease. Muslim community in Muara Teweh choose badewah as an alternative treatment solution and interpreted as a multi-function card. Badewah has been interpreted differently by the patient. The meaning is reflected in their goals and expectations. Dayak tribe believe, if suffering from disease, before or after coming to the doctor or hospital, they are also seeking for alternative treatments such as medicines kampong and traditional healer.
\end{abstract}


Perkembangan ilmu pengetahuan dan teknologi tidak bisa menggantikan makna pengobatan tradisional. Sebagian orang memilih pengobatan tradisional yang memiliki efek samping lebih sedikit, juga terkait dengan kepercayaan masyarakat. Dengan demikian, penelitian ini pada dasarnya akan mencoba menjawab permasalahan: Apa itu badewah? Bagaimana makna badewah bagi umat Muslim di Muara Teweh? Penelitian dilakukan di Kabupaten Barito Utara, Kalimantan Tengah. Data penelitian terdiri dari bahasa, tindakan, pengalaman dan sejarah. Hasil penelitian menunjukkan badewah adalah pengobatan tradisional dengan cara berdoa kepada Tuhan untuk kesehatan. Badewah dilakukan untuk mengobati penyakit irasional dan penyakit yang tak kunjung sembuh. Komunitas Muslim di Muara Teweh memilih badewah sebagai solusi pengobatan alternatif dan ditafsirkan sebagai kartu multi-fungsi dan berbeda oleh pasien. Makna pemilihan pengobatan tradisional tercermin dalam tujuan dan harapan mereka. Suku Dayak percaya, jika menderita penyakit, sebelum atau sesudah datang ke dokter atau rumah sakit, mereka juga mencari pengobatan alternatif seperti obatobatan kampung dan tabib tradisional.]

Key Word: traditional healer, badewah, rite, Muslim Society

\section{Pendahuluan}

Salah satu unsur kebudayaan daerah yang diwarisi secara turun temurun adalah pengetahuan yang berkaitan dengan pengobatan tradisional. ${ }^{1}$ Pengobatan tradisional merupakan bagian integral kebudayaan karena konsep tentang kondisi sakit dan cara

\footnotetext{
1 Pengobatan tradisional merupakan pengobatan dengan cara maupun obat yang mengacu pada pengalaman, keterampilan turun-temurun atau pelatihan yang diterapkan sesuai dengan norma yang berlaku dalam masyarakat.
} 
pengobatannya tidak berdiri sendiri. ${ }^{2}$ Perkembangan ilmu pengetahuan dan teknologi $i^{3}$ yang semakin pesat tetap tidak mampu menggeser arti pengobatan tradisional. Tidak jarang masyarakat memilih pengobatan tradisional yang dianggap memiliki efek samping lebih kecil, juga keterkaitan dengan kepercayaan yang dimiliki masyarakat. Sistem pengobatan tradisional bukan hanya sebagai fenomena medis dan ekonomi namun memiliki makna yang lebih luas yaitu sebagai fenomena sosial budaya. ${ }^{4}$

Konsep lokal tentang sakit adalah adanya gangguan terhadap pikiran dan fisik manusia sehingga mengakibatkan seseorang kehilangan konsentrasi. ${ }^{5}$ Sakit dikategorikan menjadi dua yaitu sakit yang bersifat rasional (nyata) ${ }^{6}$ dan irasional (tidak nyata). ${ }^{7}$ Dalam konsep indigenous people di Kalimantan, sakit yang bersifat tidak nyata lebih berbahaya daripada sakit yang nyata. Ada anggapan bahwa sakit yang tidak nyata dianggap sebagai teguran dari roh leluhur, atau melanggar pantangan tertentu. Dengan adanya kepercayaan terhadap roh halus yang mengganggu muncullah banyak istilah penyakit yang bersifat tidak nyata. Terkait dengan penyakit yang bersifat tidak nyata, di kalangan suku Dayak Kalimantan Tengah ada jenis pengobatan ritual yang dilakukan karena

\footnotetext{
${ }^{2}$ M. Suriansyah Ideham, dkk (ed.), Urang Banjar dan Kebudayaannya (Yogyakarta: Ombak, 2015), 119.

3 Teknologi kedokteran modern.

${ }^{4}$ M. Suriansyah Ideham, dkk (ed.), Urang Banjar, 119.

${ }^{5}$ Ibid. 121.

${ }^{6}$ Sakit yang dapat dilihat atau dirasakan bagian mana yang terasa sakit.

${ }^{7}$ Sakit yang sulit ditentukan penyebabnya, tidak dapat ditunjukkan bagian mana yang sakit, tapi dirasakan menyiksa fisik dan pikiran secara sadar atau tidak.
} 
adanya petunjuk, baik dari dalam diri sendiri (mimpi, petunjuk yang lain) atau dari orang lain. ${ }^{8}$

Pengobatan ritual ini ada beberapa macam, yaitu: (1) ritual Sangiang Bandar/ Badewah yang merupakan pengobatan berbagai macam penyakit dengan bantuan roh leluhur (Sabur Bandar) dengan Sangiang sebagai mediator $^{10}$, (2) adat Babore, upacara penyembuhan dari keluarga yang mengalami sakit (adat babore juga dikenal dengan rangkaian mengambil sumangat/semangat ${ }^{11}$; (3) adat Babuis, upacara adat menyembuhkan orang dari penyakit yang dilakukan di tempat di mana seseorang tersebut mendapatkan penyakitnya, (4) adat Balian, proses pelaksanaan adat setelah tiga hari tiga malam ada yang dinamakan basaru sumangat (ambil semangat). ${ }^{12}$

Dari beberapa jenis pengobatan ritual tersebut, penelitian ini akan difokuskan pada sangiang bandar/badewa, yaitu ritual yang dilakukan dengan meminta bantuan seorang sangiang. Pengobatan sangiang bandar/badewa cukup menarik untuk dikaji karena beberapa masyarakat Muslim juga memilih pengobatan tersebut sebagai alternatif. Dalam konteks ini, ada

\footnotetext{
${ }^{8}$ www.wikipedia.com, akses 24-10-2017.

${ }^{9}$ Sangiang adalah roh-roh leluhur (manusia ilahi) selaku utusan Tuhan yang dapat diundang kehadirannya oleh seorang basir/tabit (pendeta adat/dukun) dengan menggunakan mantra-mantra dalam bahasa Sangiang/bahasa Sangen (bahasa Dayak kuno) pada suatu upacara agama Kaharingan yang dilakukan suku-suku Dayak di Kalimantan. Pengobatan sangiang sampai saat ini dianggap sebagai pengobatan tradisional pada masyarakat Dayak Ngaju untuk menyembuhkan berbagai macam penyakit yang bersifat naturalistik atapun personalistik (pengaruh roh)

${ }^{10}$ M. Suriansyah Ideham, dkk (ed.), Urang Banjar, 130.

11 Piyoh, "Tradisi dan Pengobatan Babore", Repository.uksw.edu/bitstream, akses 24-10-

2017, 36.

12 Ibid., 39.
} 
kemungkinan bahwa para pelaku pengobatan tradisional memiliki anggapan pengobatan tersebut dapat menyembuhkan penyakit dalam dua kategori, yaitu secara fisik dan rohani. Namun pandangan tersebut ternyata tidak ditemukan pada setiap pelaku pengobatan tradisional. Mereka tetap melihat pengobatan tradisional dengan pandangan masingmasing.

Pandangan yang dikemukakan di atas menunjukkan bahwa pengobatan tradisional merupakan cara penyembuhan yang dimaknai secara berbeda oleh masyarakat Muslim. Dalam pengertian umum, makna tersebut merujuk pada pengertian yang telah diterima secara publik bahwa pengobatan tradisional merupakan salah satu cara penyembuhan. Dalam tataran private, proses pemaknaan tersebut jelas menunjukkan perbedaan antara pelaku yang satu dengan lainnya. Proses pemaknaan inilah yang menjadi fokus penelitian, ${ }^{13}$ dimana salah satu proses pemaknaan tersebut diekspresikan melalui ritual keagamaan.

Menurut Durkheim, ritual merupakan fenomena agama dalam tindakan (way of acting). ${ }^{14}$ Dengan kata lain, ritual merupakan ekspresi keyakinan dari para pelakunya. Aspek keyakinan inilah yang menuntun dan menjelaskan makna ritual yang dilakukan. Dalam hal pengobatan tradisional di Kalimantan Tengah, proses pemaknaan yang dilakukan oleh para peserta berkaitan dengan aspek keyakinan ini. Selain itu, aspek mistis

\footnotetext{
${ }^{13}$ Andri Rosadi, "Mencari Barokah dan Karomah: Analisis Makna Ziarah Makam di Situ Lengkong, Panjalu, Ciamis” (Laporan Penelitian SCME Program Kemenag, 2012), 5.

${ }^{14}$ Emile Durkheim, Sejarah Agama: The Elementary Forms of the Religious Life, terj. Inyiak Ridwan (Yogyakarta: IRCiSoD, 2003), 434.
} 
dan kepentingan individual masing-masing pelaku juga ikut membentuk ketertarikan pada makna pengobatan tradisional. Karena itu, pengobatan tradisional ini tidak hanya berkaitan dengan nilai-nilai religius, tapi juga kesehatan.

Uraian di atas menunjukkan bahwa pengobatan tradisional sebagai ritual yang dilembagakan, selalu berkaitan dengan adanya kepercayaan masyarakat pada kekuatan supranatural. Mereka yang berada dalam ruang lingkup pengaruh kepercayaan ini akan menghayati secara lebih dalam penyembuhan melalui pengobatan tradisional dan memiliki ekspektasi yang lebih tinggi untuk dapat sehat. Sebaliknya, mereka yang berada di luar ruang lingkup pengaruh tersebut akan memahami pengobatan tradisional secara lebih sederhana dengan ikatan emosional yang tidak terlalu dalam. Dalam konteks inilah, proses pemaknaan berlangsung.

Pengobatan tradisional, dengan segala nilai yang diberikan kepadanya merupakan simbol yang merangkum banyak makna. Berkaitan dengan kajian makna, permasalahan yang perlu diidentifikasi lebih lanjut adalah: (1) apa yang dimaksud dengan badewah? dan (2) bagaimana makna pengobatan tradisional badewah menurut masyarakat Muslim Muara Teweh.

Penelitian dilakukan di Muara Teweh, Kabupaten Barito Utara, Propinsi Kalimantan Tengah. Hal yang menarik di lokasi ini adalah terdapat beberapa praktik pengobatan tradisional yang menjadi pilihan masyarakat. Muara Teweh menjadi bermakna karena adanya pengobatan tradisional yang diyakini memiliki kekuatan bealing yang cukup kuat dengan mayoritas penduduknya Muslim. Muara Teweh sebagai ibukota Barito 
Utara sudah bersentuhan dengan kemajuan teknologi medis. Namun demikian, hal tersebut tidak mampu menghilangkan pengobatan tradisional yang diperoleh secara turun temurun. Dapat dikatakan bahwa pengobatan tradisional suku Dayak tetap eksis hingga sekarang.

Data penelitian berupa "bahasa", tindakan, pengalaman dan sejarah. Data bahasa berupa ungkapan atau percakapan para pelaku pengobatan tradisional. Mantra ataupun bacaan yang diucapkan para pelaku pengobatan tradisional juga termasuk kategori data bahasa. Spradley menyatakan bahwa bahasa memegang peran yang cukup besar dalam pengalaman manusia. Bahasa lebih dari sekedar alat mengkomunikasikan realitas, melainkan juga merupakan alat untuk menyusun realitas. Data tindakan merupakan perilaku yang dilakukan oleh pelaku pengobatan tradisional, selama mereka berobat dan dianggap penting oleh peneliti. Setiap perilaku memiliki nilai, dan nilai mirip dengan kata-kata. Maka akan nampak bahwa data perilaku dan bahasa ada hubungan yang erat.

Data pengalaman merupakan pengalaman mereka yang terlibat dalam pengobatan tradisional. Data sejarah selain berbentuk dokumen, juga meliputi oral bistory yang diwariskan secara turun temurun dalam masyarakat tersebut. Hal ini menjadi mungkin jika tradisi oral history masih ada di masyarakat tersebut. Data sejarah diperlukan untuk mengetahui latar historis mengenai pengobatan tradisional yang sampai saat ini masih eksis. Tradisi demikian masih hidup di kalangan masyarakat Indonesia secara umum. Wilayah Kalimantan Tengah dikenal dengan istilah tetek tatum, yaitu merupakan cerita asal-usul suku Dayak yang diwariskan secara 
tutun temurun.

Data bahasa yang berupa ungkapan, percakapan, maupun mantra pengobatan yang diucapkan dapat dikumpulkan dengan cara mendengar dan wawancara. Metode mendengar ${ }^{15}$ dalam penelitian etnografi dirasa perlu untuk mendapatkan ungkapan-ungkapan baik yang terencana maupun spontan selama proses pengobatan. Sedangkan untuk mendapatkan informasi yang lebih mendalam digunakan metode wawancara. Dalam penelitian ini informan dikategorikan menjadi dua: pengobat tradisional dan pasien Muslim. Pengumpulan data perilaku bisa diperoleh melalui observasi langsung proses pengobatan tradisional. Dengan cara seperti ini, peneliti dapat melakukan cross-check guna melihat kesesuaian ucapan dan tindakan. Untuk data sejarah peneliti melakukan studi pustaka ${ }^{16}$ dan wawancara. ${ }^{17}$

\section{Mengenal Beberapa Pengobatan Tradisional}

Sistem pengobatan tradisional/pengobatan asli adalah pranata sosial yang harus dipelajari dengan cara yang sama seperti mempelajari pranata sosial umumnya. Praktik pengobatan asli adalah rasional jika dilihat dari sudut kepercayaan yang berlaku mengenai sebab akibat. Setelah antropologi kesehatan berkembang terutama dalam bidang-bidang yang luas, konsep kesehatan internasional dan psikiatri lintas budaya (psikiatri

\footnotetext{
15 Prof. Heddy Ahimsa dalam materi SCME (Suryalaya, 2012).

${ }^{16}$ Digunakan untuk mengumpulkan data yang telah ada dokumentasinya

${ }^{17}$ Digunakan untuk menghimpun cerita yang berkembang di masyarakat berkaitan dengan sejarah pengobatan tradisional.
} 
transkultural), kepentingan pengetahuan praktis maupun teoritis mengenai pengobatan non-Barat semakin tampak. Pengakuan tersebut telah memperbaharui perhatian dalam penelitian ethno medicine dan mengangkatnya sebagai salah satu pokok penting dalam penelitian antropologi kesehatan. ${ }^{18}$

Sistem pengobatan tradisional merupakan fenomena sosial budaya. Di negara-negara seperti Cina, India, Vietnam dan Jepang, pengobatan tradisional telah diakui dan dijadikan lembaga resmi secara nasional oleh pemerintah negara tersebut. Sebagian besar bentuk institusi dan pendidikan profesi telah disesuaikan dengan pengobatan asli. Bahkan World Heath Organization (Organisasi Kesehatan Dunia) tidak menutup mata akan pentingnya pengobatan tradisional bagi penduduk dunia umumnya. Dasar kebijaksanaan dari Program Pengobatan Tradisional (the Traditional Medicine Programme) yang diadopsi oleh The World Health Assembly and the Regional Committes, menunjukkan perhatian pada kenyataan: 1) secara umum penduduk dunia percaya pada pengobatan tradisional untuk perawatan kesehatan yang pertama, 2) tenaga kerja diwakili oleh ahli pengobatan tradisional adalah sumber yang potensial dari penyampaian perawatan kesehatan. ${ }^{19}$

Di Indonesia, praktik pengobatan tradisional belum secara resmi diakui oleh pemerintah. Namun pengobatan tradisional semakin

\footnotetext{
${ }^{18}$ Darwis, dkk., Kesehatan Masyarakat dalam Perspektif Sosioantropologi (Makasar: Sah Media, 2017), 200.

19 Akarele dalam Nanik Kasniyah, "Fenomena Budaya dalam Penyembuhan Penyakit Secara Tradisional: Pijat Refleksi dan Transfer Penyakit dengan Media Binatang", Jurnal Masyarakat Kebudayaan dan Politik, No. 4 (Tahun 22), 334.
} 
berkembang walaupun masih dalam tingkat rumah tangga atau masyarakat. Dalam sistem kepercayaan sehubungan dengan penyembuhan penyakit, peranan penyembuh menjadi penting. Satu hal yang telah berubah sekarang adalah sebutan dukun dikenal dengan penyembuh alternatif. Keduanya secara ilmiah disebut sebagai penyembuh tradisional (traditional healer) dalam sistem kesehatan tradisional (ethno-medicine). Walaupun ada perubahan sebutan, namun dalam praktiknya masih menggunakan pola lama. ${ }^{20}$

Sejalan dengan itu, pengobatan tradisional yang dikenal oleh masyarakat suku Dayak di Kalimantan adalah pengetahuan yang diwarisi dari para orang tua dan ahli pengobatan tradisional yang ada di daerah mereka. Pengetahuan pengobatan telah menjadi bagian hidup mereka karena selalu digunakan dalam pengobatan. Pengetahuan itu diperoleh secara temurun, ataupun mempelajari secara khusus dan tidak setiap orang sanggup melaksanakannya karena ada persyaratan yang harus dipenuhi.

Di Uzbekistan, pengobatan tradisonal tergambar pada praktik pengobatan dan kepercayaan Islam, pengajaran medis Avicena dan tradisi perdukunan. Sebuah epistemologi lokal Uzbek tentang penyakit dan penyembuhan, memungkinkan bahwa penyakit dan mental atau ketidakseimbangan emosional mungkin nyata, penyebab fisik juga mungkin berhubungan dengan roh jahat. Sebuah pemahaman bersama bahwa Allah mengirimkan penyakit juga mengirimkan penyembuhannya untuk membentuk sikap keterbukaan terhadap pendekatan perawatan,

${ }^{20}$ Nanik Kasniyah, "Fenomena Budaya...., 342. 
dari bio-medicine barat ke pembacaan Alquran dan dari perawatan herbal. ${ }^{21}$

Sebutan untuk penyembuh tradisional berbeda antara satu kawasan dengan lainnya. Sebutan yang paling umum adalah traditional bealer (penyembuh tradisional). Di Thailand disebut mor baan, di Uzbekistan disebut tabibs, terkadang juga digunakan kata naturopaths/ herbal healers, di Indonesia sebagian masyarakat Jawa menggunakan istilah dukun, dan di Kalimantan istilah yang lebih dikenal adalah balian. Secara khusus suku Dayak Hindu Kaharingan (DHK) menyebutnya dengan tabit/lasang. Mereka yang mendapat julukan ini di masyarakat biasanya dikunjungi masyarakat sebagai perantara penyembuhan penyakit. Di Thailand, ${ }^{22}$ penyembuh tradisional (mor baan) sebagai sumber utama pengobatan tradisional untuk rakyat, khususnya di pedesaan. Meskipun pengobatan modern telah mengalami perkembangan dan peningkatan yang pesat, penyembuh tradisional tidak pernah menghilang dari masyarakat Thailand karena praktik mereka telah menyatu ke dalam gaya hidup masyarakat awam.

${ }^{21}$ Z. Tursunova, M. Kamp, N. Azizova \& L. Azizova, "Cultural Patterns of Health Care Beliefs and Practices among Moslem Women in Uzbekistan", Journal Health, Culture and Society, Vol. 6 No. 1 (2014), http://hcs.pitt.edu, 58.

${ }^{22}$ Dusanee Suwankhong, Pranee Liamputtong, Bruce Lumbold, "Existing Roles of Traditional Healers (Mor Baan) in Southern Thailand", J Community Health No. 36 (2011), 438-445, DOI 10 1007/s10900-011-9360-z. 


\section{Sejarah Ritual Badewah}

Suku Dayak di Kalimantan Tengah telah mengenal sistem pengobatan tradisional yang diwariskan secara turun-temurun dan disebut "obat kampung" dan praktisi medisnya disebut dengan tabit/lasang. Hingga kini, walaupun ilmu dan teknologi kedokteran sudah mengalami kemajuan pesat, eksistensi obat kampung sebagai sumber alternatif masih tetap berfungsi dalam masyarakat suku Dayak. ${ }^{23}$ Kepercayaan suku Dayak terhadap pengobatan tradisional masih kuat, sekalipun pelayanan kesehatan modern telah merata di kalangan masyarakat. Jenis-jenis penyakit tertentu disebabkan oleh faktor medis dan nonmedis (supranatural) dan penyakit yang tak kunjung sembuh. Bagi masyarakat Dayak, yang tinggal di desa atau kota, kepercayaan terhadap gangguan kesehatan yang disebabkan oleh gabungan faktor naturalistik dan personalistik hingga kini masih menjadi faktor motivasi yang signifikan terhadap penggunaan pengobatan tradisional sebagai alternatif pertama di samping pengobatan medis. ${ }^{24}$

Tak dapat dipungkiri bahwa, secara umum pandangan masyarakat Indonesia terhadap penyakit disebabkan karena faktor personalistik (makhluk halus) dan faktor naturalistik (fisikal). Penyakit yang disebabkan oleh faktor personalistik akan berbeda pengobatannya dengan yang disebabkan faktor naturalistik. Jika yang pertama diobati dengan kekuatan

\footnotetext{
${ }^{23}$ Kadek Sukida, "Sistem Medis Tradisional Suku Dayak Dalam Kepercayaan Hindu Kaharingan di Kota Palangkaraya, Provinsi Kalimantan Tengah", Jurnal Dharmasmrti, Vol. XIII Nomor 26 (Oktober 2015), 52.

${ }^{24}$ Ibid., 53.
} 
gaib (mantra, doa, atau gabungan mantra dan ramuan), maka yang kedua pengobatannya menggunakan ramuan dari bahan-bahan tumbuhan dan hewan atau gabungan keduanya. ${ }^{25}$

Salah satu pengobatan tradisional yang dijadikan alternatif bagi suku Dayak adalah badewah, ritual khas Suku Bakumpai yang merupakan sub suku Dayak Ngaju. Upacara ini bertujuan untuk menyembuhkan orang sakit (batatamba dalam bahasa Banjar). Upacara badewah tumbuh dan berkembang sebelum Islam masuk Kabupaten Barito Utara. Secara umum dalam masyarakat tradisional Indonesia pengetahuan lokal tentang pengobatan tradisional kebanyakan terekam dalam ingatan lisan masyarakatnya. ${ }^{26}$ Sebagai contoh, ketika anggota ${ }^{27}$ sebuah keluarga di Barito Kuala (Suku Bakumpai) yang mempercayai kekuatan roh-roh gaib terserang sakit, orangtua berupaya mencari ramuan tumbuh-tumbuhan yang akan digunakan sebagai obat, tapi si pasien tak kunjung sembuh. ${ }^{28}$ Akhirnya mereka pasrah kepada Yang Maha Kuasa. Dengan berbagai mantera, sang ayah memanggil roh-roh nenek moyang mereka yang dianggap mempunyai kesaktian. Selain diminta datang sebagai perantara penghubung dengan para Dewa, salah seorang anggota keluarga yang sehat langsung kesurupan dimasuki roh gaib. Kemudian keluarga yang kesurupan mengambil daun sawang. Daun tersebut beberapa kali

\footnotetext{
${ }^{25}$ Dadang Susena, dkk., "Pengobatan Tradisional dalam Naskah-Naskah Minangkabau: Inventarisasi Naskah, Teks dan Analisis Etnomdisin Wacana Etnik, Jurnal Ilmu Sosial dan Humaniora, Vol. 4 No. 2 (2013), 140.

${ }_{26}$ Dadang Susena, dkk., "Pengobatan Tradisional, 142.

27 Berdasar oral history yang berkembang di masyarakat.

28 http:/ /www.radarbanjarmasin.com/, akses 07-11-2017.
} 
diusapkan dan diurutkan ke sekujur tubuh si sakit. Setelah itu keluarlah benda, berupa potongan kaca, paku, atau pasak ulin dari tubuh si sakit. Dengan segala keajaiban, keluarga yang terserang sakit pun sembuh. Cerita kesembuhan tersebut kemudian menyebar ke seluruh pelosok.

Sejarah keberadaan pengobatan tradisional bisa dikatakan sejalan dengan keberadaan suku Dayak itu sendiri. Hal ini tidak terlepas dari kosmologi suku Dayak Hindu Kaharingan yang meyakini bahwa sehat dan sakit (barigas dan haban) karena faktor-faktor alam, manusia dan roh. Kosmologi suku Dayak terbagi menjadi dua, yaitu kosmologi lisan (tetek tatum/cerita dari nenek moyang suku Dayak Hindu Kaharingan) dan kosmologi tulisan (dalam bentuk kitab Panaturan). ${ }^{29}$

Sistem keyakinan terhadap sehat dan sakit lebih terfokus pada sebabsebab terjadinya suatu penyakit. Konsep terjadinya suatu penyakit tidak hanya disebabkan oleh faktor alamiah, tetapi juga dapat dilakukan oleh orang atau bukan orang. Penggolongan penyebab penyakit (etiologi) akan berpengaruh terhadap upaya penanggulangan yang dilakukan, berkenaan dengan bagaimana dan kepada siapa harus meminta pertolongan sekaligus pemberian label terhadap jenis penyakit yang diderita. ${ }^{30}$

Dalam tetek tatum diuraikan bahwa dunia pengobatan tradisional meyakini keberadaan dewa-dewa sebagai penganugerah kesembuhan dan pengetahuan pengobatan. Pandangan tersebut menunjukkan bahwa pengobatan tradisional lebih dominan penanggulangan penyakit secara

\footnotetext{
${ }^{29}$ Kadek Sukida, "Sistem Medis", 54.
}

${ }^{30} \mathrm{Ibid}, 55$. 
irasional, melalui pemujaan dewa-dewa yang dipanggil agar dapat menanggulangi suatu penyakit. Suku Dayak sampai saat ini masih percaya, bahwa sebelum atau sesudah datang ke dokter atau rumah sakit, mereka juga harus mencari pengobatan alternatif dengan obat kampung melalui tabit (dukun) suku Dayak. ${ }^{31}$

Bentuk pengobatan dalam kitab Panaturan termuat pada pasal 40 ayat 2 dan 19, menunjukkan bahwa Ranying Hatalla (Yang Maha Kuasa dalam kepercayaan suku Dayak Ngaju) mengubah wujudnya menjadi Manyamai Tunggul Garing (Unsur langit sebagai filosofis simbol bapak) dan Kameluh Tanteluh Petak Unsur tanah sebagai simbol ibu) yang memiliki kesaktian untuk mengobati orang sakit (baban), bahkan dapat menghidupkan kembali orang yang telah meninggal dunia. Apabila seseorang dalam keadaan sakit (baban) dan meminta pertolongan pengobatan dengan menggunakan ritual pengobatan suku Dayak, hendaknya mengikuti pantangan (pali) yang ditetapkan oleh tabit/lasang agar penyakit yang diderita bisa sembuh. Apabila melanggar maka kemanjuran obat tersebut akan hilang. Keyakinan dan kepatuhan terhadap pali sangat menentukan keberhasilan pengobatan segala macam jenis gangguan penyakit. ${ }^{32}$

Sejalan dengan masuknya ajaran Islam, pengobatan tradisional mengalami pergeseran baik makna maupun pelakunya. Keislaman suku Bakumpai, sebenarnya tidak serta merta mencerabutkan mereka dari keturunannya. ${ }^{33}$ Menarik diamati bahwa tabit badewah yang beragama Islam

\footnotetext{
${ }^{31}$ Ibid, 56.

${ }^{32}$ Ibid. 58.

${ }^{33}$ Raja Syaff, http://radhahera.blogspot.co.id/2011/, akses 09-11-2017, 1.
} 
meyakini bahwa apa yang dia lakukan adalah untuk mengobati dan tidak bertentangan dengan agama yang dianutnya.

\section{Ritual Badewah di Muara Teweh}

Sebagai upaya mempertahankan suatu budaya, masyarakat dan pemerintah memiliki tanggung jawab besar untuk memperkenalkan budaya lokal yang terkait dengan sistem kesehatan yang dikenal dengan pengobatan tradisional. Ketika peneliti berkunjung ke Muara Teweh, pemerintah setempat senantiasa menggalakkan pengobatan tradisonal. Pemerintah juga melakukan usaha dengan menyebarluaskan informasi pelaksanaan ritual badewah. Penyebarluasan pamflet dan buku panduan wisata juga digunakan sebagai salah satu upaya memperkenalkan ritual badewah secara luas. Hal ini sangat membantu, terutama bagi penduduk pendatang yang sebagian besar belum mengenal budaya setempat. ${ }^{34}$

Pengenalan pengobatan tradisional secara alamiah maupun terprogram, baik yang dilakukan pihak keluarga, masyarakat ataupun pemerintah, membawa kepada proses membudaya nilai badewah dalam kehidupan setiap individu sehingga tertanam dalam kehidupannya. Sebuah

\footnotetext{
${ }^{34}$ Salah satu tim dari peneliti adalah warga asli Muara Teweh. Hal ini mempermudah akses masuk ke dalam komunitas pelaku badewah di Muara Teweh, penerimaan mereka lebih terbuka terhadap keberadaan peneliti. Dengan alasan etika penelitian, peneliti menyampaikan sedikit indentitas diri, maksud dari penelitian ini dan menyatakan bahwa identitas informan tidak akan diekspos. Dengan demikian, beberapa informan merasa lebih bebas untuk menyampaikan informasi terkait dengan ritual badewah tersebut.
} 
tradisi yang melekat kuat dalam kehidupan seseorang menyebabkan sulitnya merubah tradisi yang telah mengakar dalam masyarakat. ${ }^{35}$

Pada dasarnya pengenalan ritual badewah selain dilakukan secara individual oleh masyarakat didukung juga oleh penguasa. Seperti yang dilakukan oleh Bupati Barito Utara, ${ }^{36}$ yang melakukan peningkatan budaya di Barito Utara melalui berbagai cara, seperti mengadakan ritual badewah. Usaha pembudayaan ritual badewah didukung dengan memperkenalkannya sehingga tersebar secara luas di kalangan masyarakat. Upaya menumbuhsuburkan ritual badewah dilakukan juga oleh Dinas Pariwisata dan Kebudayaan serta instansi pemerintahan yang lainnya.

Adanya faktor yang mengancam eksistensi tradisi di Muara Teweh menjadi salah satu faktor yang mendorong pemerintah untuk menjaga kelestarian budaya. Karenanya, pemerintah mendukung penuh upaya pembudayaan ritual badewah di tengah masyarakat. Pembudayaan yang dilakukan oleh pemerintah maupun masyarakat dalam waktu yang lama menyebabkan ritual badewah masih melekat di kalangan masyarakat Muara Teweh, walaupun mereka mengalami pergeseran budaya. ${ }^{37}$

Upaya memperkenalkan ritual badewah dilakukan melalui berbagai tahap sejak dari awal masa kanak-kanak sampai pada tingkat yang paling tinggi dalam usia dewasa. Hal itu dilakukan dalam dua tataran, yaitu 1) tingkat komunitas, memperkenalkan ritual badewah sebagai suatu sarana

\footnotetext{
35 Sri Suhandjati, "Dinamika Nilai Jawa Islam dan Tantangan Modernitas" dalam Darori Amin (ed.), Islam dan Kebudayaan Jawa (Yogyakarta: Gama Media, 2000), 283.

${ }^{36}$ Adanya dukungan bupati dan pemerintah daerah Barito Utara terhadap pembudayaan ritual badewah.

${ }^{37}$ Sri Suhandjati, "Dinamika Nilai", 285.
} 
pengetahuan tentang kesehatan dan pengobatan tradisional; 2) tingkat individual, memperkenalkan ritual badewah sebagai proses suatu masyarakat dalam membentuk pandangan-pandangan tentang kesehatan dan pola pengobatan mereka. Dalam konsep ini, Mead memandang individu sebagai aktor yang aktif, sehingga proses pengenalan budaya merupakan proses yang beraspek ganda. ${ }^{38}$

Dalam proses perubahan kebudayaan ada unsur-unsur kebudayaan yang mudah berubah dan yang sukar berubah. Berkaitan dengan hal ini, Linton membagi kebudayaan menjadi inti kebudayaan (covert culture) dan perwujudan kebudayaan (overt culture). Bagian inti kebudayaan terdiri dari sistem nilai budaya, keyakinan keagamaan yang dianggap keramat, beberapa adat yang telah mapan dan tersebar luas di masyarakat. Bagian inti kebudayaan sulit berubah, sementara wujud kebudayaan yang merupakan bagian luar/fisik dari kebudayaan seperti alat-alat atau bendabenda hasil seni budaya, mudah untuk berubah. ${ }^{39}$

Berdasarkan hal tersebut di atas, maka badewah di Muara Teweh yang sulit berubah adalah hal yang terkait dengan adat istiadat. Dalam konteks terjadinya perubahan ke arah modernisasi, maka ritual badewah dihadapkan pada tantangan budaya global yang memiliki nilai dan perwujudan budaya yang pluralistik. Sebagai pengobatan tradisional ritual badewah memiliki nilai universal, di samping nilai lokalnya. Di antara nilai universalitas itu terletak pada nilai spiritualnya yang religius magis. Sebagian besar

\footnotetext{
${ }^{38}$ Slamet Subiyantoro, "Proses dan Pola Enkulturasi Seni Ukir di Dukuh Taraman, Desa Mantingan, Kabupaten Jepara, Jawa Tengah” (Tesi -- UI Jakarta, 1998), 100.

${ }^{39}$ Ibid.
} 
masyarakat masih merasa perlu memegang teguh tradisi karena diperlukan untuk menghadapi tantangan hidup yang muncul di abad modern. ${ }^{40}$

Tradisi yang mengakar lama di masyarakat, yang oleh Linton dimasukkan dalam wilayah covert culture, memang yang sulit berubah. Namun dalam kenyataan di masyarakat, ada pula tradisi yang telah mengalami pergeseran sehingga dipandang tidak memiliki nilai magis lagi. Misalnya, rangkaian ritual pengobatan, seperti baboreh dan sangiang/badewah, yang dahulu memiliki nilai religius magis, tetapi di masa modern ini sudah mengalami perubahan. Bahkan, sebagian masyarakat menganggap hanya sebuah tradisi yang dipertahankan tanpa mengetahui lebih dalam maknanya.

Perubahan budaya di era modern lebih banyak terjadi pada wilayah overt culture. Dalam realitasnya, beberapa unsur dalam ritual badewah memang mengalami perubahan sesuai dengan perkembangan zaman. Namun demikian, perubahan adalah inti kehidupan. Tak ada yang tetap di dunia ini. Semuanya terkena hukum perubahan, baik yang bergerak linier maupun sirkuler. Perubahan bisa menyangkut kehidupan manusia yang terkait dengan lingkungan kehidupannya yang berupa fisik, alam maupun sosial budaya. Di sisi lain perubahan juga menyangkut pada level individu, interaksi organisasi, komunitas, institusi, masyarakat, kebudayaan dan global. Keduanya berbeda dalam memandang perubahan satu mengenai

40 Slamet Subiyantoro, "Proses dan Pola, 286. 
faktor eksternal perubahan dan yang lainnya terkait dengan peringkat perubahan. $^{41}$

Secara teoritis perubahan kebudayaan mencakup lima hal pokok. Pertama, perubahan sistem nilai dengan proses integrasi ke disintegrasi. Untuk selanjutnya menuju ke reintegrasi. Kedua, perubahan sistem makna dan sistem pengetahuan, yang berupa penerimaan suatu kerangka makna (kerangka pengetahuan), penolakan dan sikap penerimaan makna baru dengan proses orientasi ke disorientasi ke reorientasi sistem kognitifnya. Ketiga, perubahan sistem tingkah laku yang berproses dari penerimaan tingkah laku, penolakan dan penerimaan tingkah laku baru. Keempat, perubahan sistem interaksi, dimana akan muncul gerakan sosialisasi melalui disosialisasi ke resosialisasi. Kelima, perubahan sistem kelembagaan/ pemantapan interaksi, yakni pergeseran dari tahapan organisasi ke disorganisasi ke reorganisasi. ${ }^{42}$

Pada masyarakat Muara Teweh, perubahan dapat dilihat dari tiga hal utama: (1) perubahan dari kerangka makna, dengan semakin berkurangnya pengetahuan masyarakat Muara Teweh tentang ritual badewah, karena ketiadaan teks-teks yang mendukung untuk pelestarian tradisi tersebut, (2) dalam ranah tingkah laku, di mana kalangan generasi muda cenderung untuk tidak terikat dan mudah menyerap tingkah laku baru yang berasal dari luar dan pada gilirannya akan mempengaruhi lingkungannya. (3) perubahan tindakan yang terjadi di generasi muda pada masyarakat Muara

\footnotetext{
${ }^{41}$ Nur Syam, Madz̧hab-Madz̧hab Antropologi (Yogyakarta: LKiS, 2007), 159.
}

${ }^{42}$ Ibid., 169. 
Teweh yang dipicu oleh berbagai interaksi yang intensif dengan dunia luar akibat urbanisasi dan juga faktor pendidikan. Semakin banyak anak yang berpendidikan tinggi semakin tinggi kemandirian untuk melakukan tindakan. Secara konsepsional teoritik, mereka menjadi semakin rasional atau dalam konsepsi Weber disebut tindakan rasional bertujuan, yaitu tindakan yang didasari oleh berbagai motif dan keinginan yang bersesuaian dengan tujuan hidup. ${ }^{43}$

Ketika terjadi komunikasi antar budaya, misalnya antara budaya lokal di Muara Teweh dengan Islam yang datang kemudian, tidak menyebabkan budaya lokal di Muara Teweh (sebagai contoh ritual badewab) luntur, tetapi justru diperkaya dan diperhalus, melalui proses akulturasi. ${ }^{44}$ Perubahan akan terus berlangsung meskipun di antara perubahan tersebut masih menyisakan ruang yang ajeg, tidak berubah. Terdapat varian tradisi pada masyarakat Muara Teweh yang mengalami proses perubahan dengan tetap mempertahankan apa yang dianggap sebagai inti budaya.

\section{Ritual Badewah: Perspektif Antropologi}

Bagian ini merupakan catatan penelitian tentang ritual badewah di dalam kegiatan Bawayang dan Batuping Manyanggar yang diselenggarakan oleh pemerintah daerah Kabupaten Barito Utara ditinjau dari perspektif antropologi. Pada bagian ini digambarkan riwayat hidup (individual life history) pengobat tradisional dan beberapa pasien yang

\footnotetext{
${ }^{43}$ Nursyam, Madz̧hab-Mad₹̧̧ab, 182.

44 Sri Suhandjati, "Dinamika Nilai .....", 290.
} 
masih melakukan ritual badewah untuk mendapatkan makna secara fonemik dari kegitan ritual tersebut.

\section{Dinamika Ritual Badewah}

Menggunakan metode diakronik, peneliti mengkaji kebudayaan suku Dayak pada suatu waktu tertent kemudian dikaji lagi beberapa saat kemudian. cara digambarkkan untuk menggambarkan unsur-unsur yang tetap dan berubah dalam ritual badewah. Perubahan dengan demikian dapat diketahui secara relatif eksak, dengan melihat mana unsur yang tetap dan mana unsur yang berubah ${ }^{45}$ (continuity and change).

Kajian ini juga diarahkan untuk melihat perubahan di tengah kontinuitas. Perubahan tersebut menyangkut pandangan masyarakat tentang praktik kehidupan, dalam hal ini ritual badewah dikaitkan dengan perubahan-perubahan pengalamannya. ${ }^{46}$ Kenyataannya, di kalangan terdidik muslim terdapat keinginan untuk memadukan antara yang lama dan baru (atau antara budaya lokal dengan Islam). Menurut Niels Mulder, perubahan menyangkut gaya hidup masyarakat dalam kaitannya dengan bentuk baru dari agama, seni budaya dan kehidupan sosial. Mereka telah melakukan perubahan-perubahan interpretasi tentang kehidupan sehariharinya. Untuk mengkaji continuity and change dalam ritual badewah, penelitian ini fokus pada komponen ritual tersebut, yakni tempat, waktu, orang yang terlibat dan peralatan.

\footnotetext{
${ }^{45}$ Nursyam, Madz̧hab-Madz̧ab, 21.

${ }^{46}$ Ibid., 59.
} 
Berbagai perubahan di tengah kontinuitas terjadi dalam ritual badewah, setidaknya dalam empat komponen ritual. Pertama, tempat penyelenggaraan. Dalam hal ini ada yang tetap dan berubah. Penyelenggaraan yang dilakukan di rumah tabit, maka pasien akan mendatangi rumah tabit. Sedangkan penyelenggaraan yang dilakukan dalam rangka Hari Ulang Tahun (HUT) Kabupaten Barito Utara dilaksanakan oleh Dewan Adat Dayak (DAD) Barito Utara, pasien mengambil tempat di gedung terminal AKAP, Wayang, jalan Koyem. Kedua, waktu penyelenggaraan. Jika dilakukan di rumah tabit, jadwal pengobatan sesuai dengan waktu yang telah ditentukan oleh tabit. Sementara waktu penyelenggaraan yang dilaksanakan oleh Dewan Adat Dayak Barito Utara, pada saat penelitian ini dilaksanakan tanggal 29 s.d 31 Juli 2017. Ketiga, orang yang terlibat. Pada saat ini orang-orang yang terlibat dalam ritual badewah lebih beragam. Orang yang terlibat secara garis besar terbagi menjadi dua, dilihat dari keragaman agama dan keragaman suku. Keempat, peralatan yang tetap dipertahankan hingga sekarang adalah piduduk panggung, piduduk uringi, catatan piduduk dan sesajen. Keempat hal tersebut harus ada dalam pelaksanaan ritual badewah. Meskipun seiring perkembangan zaman, terdapat perubahan dalam bentuk dan sedikit pergeseran makna. Perubahan-perubahan ini menjelaskan dari pergeseran makna dan bentuk ritual tersebut terkait dengan sisi ekonomi dan struktur- 
struktur sosial yang ada, yang pada ahirnya bisa berpengaruh pada eksistensi ritual badewab. ${ }^{47}$

\section{Pelaksanaan Ritual Badewah}

Pada tahun 2017 pemerintah Barito Utara, menyelenggarakan kegiatan "Adat Batuping: Manyangggar Mampasih Lebu”. Kegiatan dilaksanakan selama tiga hari, ${ }^{48}$ Pada hari pertama dilaksanakan "Acara Batuping: dalam rangka Manyanggar Memparasib Lebu'. Kegiatan ini meliputi bermula, batatabur, baundang-undang, basaru-saru lawan orang warga luka warga kayangan. Kegiatan ini sebagai simbol mengundang makhluk halus. Mantra yang digunakan dalam bahasa lokal. Seiring dengan masuknya Islam ke wilayah tersebut, disampaikan beberapa hal dalam ritual tersebut mengalami pergeseran makna. Dalam pelaksanaan ritual, dalam peserta Muslim tidak meninggalkan waktu shalat. Pada waktu azan berkumandang, ritual berhenti. lalu dilanjutkan lagi. Hari kedua dilaksanakan "Batarima Dadaharan dari Urang Bumi Lamah Bumi Rata. ${ }^{49}$ Hari ketiga merupakan puncak ritual, yaitu Lurah Pantul dan Lurah Tamban, Diang Pangina dan Diang Pangamban menerima perintah Raden ${ }^{50}$ gasan mancari jalan, mancari luring ka mandi asam. ${ }^{51}$

Peralatan dalam ritual ini disiapkan oleh panitia berdasar arahan dari tabit. Masing-masing sudah membagi tugas dalam menyiapkan peralatan

\footnotetext{
${ }^{47}$ Julianus Limbeng, "Strategi Bertahan Jaipong Lingkar Seni Budaya Bekasi” (Disertasi -- UI Jakarta, 2012), 173.

${ }^{48}$ Tanggal 29 s.d 31 Juli 2017.

${ }^{49}$ Dimaknai sebagai adanya penerimaan persembahan dari orang bumi.

${ }^{50}$ Pelaku utama dan pemimpin dalam pelaksanaan ritual.

${ }^{51}$ Tim pelaku ritual mulai mengadakan interaksi dalam rangka pengobatan bagi pasien.
} 
yang akan digunakan dalam ritual. Pemerintah mempersiapkan tempat berlangsungnya acara dan menyiapkan makanan untuk ritual tersebut. Dalam ritual ini ada media khusus yang dianggap dapat menghubungkan dengan dengan dewa/roh. ${ }^{52}$ Salah satunya adalah mayang ${ }^{53}$ yang diambil dari pohon pinang.

Sedangkan perlengkapan dan persyaratan untuk kegiatan ritual badewah yang terdapat dalam kegiatan bawayang dan batuping manyanggar, meliputi:

a) Piduduk Panggung terdiri dari: $7 \mathrm{~kg}$ beras, $7 \mathrm{~kg}$ gula putih, 7 butir kelapa, 7 biji gula merah, pisau dan tombak.

b) Piduduk Uringin terdiri dari: $7 \mathrm{~kg}$ beras, 7 karakup/ganggam beras, 7 kajumput beras, 2 lembar kain bahalai, 4 macam kain untuk bendera (kuning, hijau, merah dan biru), tempat baki untuk duit tabur.

c) Catatan Piduduk terdiri dari: 1 piduduk mamalas wayang, 1 piduduk mamalas panggung basar, 1 piduduk mamalas panggung kacil, 1 piduduk mamalas dadalang, 1 piduduk mamalas gumalan, 1 piduduk mamalas batara kala ada beliung, 1 piduduk mamalas urang ampun gawi.

d) Sesajen, ${ }^{54}$ merupakan syarat ritual yang berupa bahan-bahan yang sudah dimasak, terdiri dari: wadai kakulih; madu kasirat; wadai wajik, wadai gandang ramas, wadai gagatas, bubur bakatul 7 gelas + sarikaya, tumpi angin, dodol, wadai telapak batis, cingkaruk batu + telur + pisang, cingkaruk batutuk + pisang, tapai pulut (hak tuping), nasi bima

\footnotetext{
${ }^{52}$ Seiring dengan masuknya agama Islam, hal ini mengalami pergeseran makna.

${ }^{53}$ Digantung dengan ketinggian sekitar 2 meter.

${ }^{54}$ Kata sesajen adalah bahasa lokal yang dalam bahasa Indonesia merupakan sesajian.
} 
+ 7 telur bakambang mayan, nasi halarat, nasi kiparat, nasi salamat, punjung tumpang, punjung ampat, lamang $7+1$ lamang tongkat + ayam, ketupat 7 biji, lapat dan cucur, kopi pahit -kopi manis dan air putih, 6 ekor ayam kampung-ayam merah-ayam putih-ayam tulak dan ayam kuning.

Piduduk merupakan syarat ritual berupa bahan-bahan mentah. Biasanya terdiri dari beras (simbol kesejahteraan), kemudian di atas beras disusun bahan-bahan lain seperti: kelapa (kelimpahan kebaikan) yang sabut kelapanya telah dikupas terlebih dahulu dengan menyisakan bagian atasnya. Pada sabut bagian atas tersebut, ditusukkan jarum (kecil tapi bermanfaat besar) dengan benang (ikatan keluarga). Di sekeliling kelapa diletakkan bumbu dapur (simbol bagi anak perempuan agar pandai memasak) dan ada juga yang menambahkan uang koin (manfaat bagi siapaun). Piduduk merupakan tanda terima kasih pada bidan atas bantuannya dalam proses kelahiran.

Sesajen merupakan syarat ritual yang berupa bahan-bahan yang sudah dimasak. Sesajen ini dibedakan menjadi dua, sesajen pokok dan sesajen pengiring. Sesajen pokok adalah sesajen yang harus ada dan tidak boleh ditinggalkan, biasanya terdiri dari nasi ketan (nasi lamak) kuning dan putih, telur, kue-kue tradisional. Sedangkan sesajen pengiring biasanya berupa bermacam-macam penganan, apalagi zaman sekarang terdapat bermacam makanan yang dapat dengan mudah didapatkan di pasaran.

Sebelum ritual dimulai, untuk kelancaran kegiatan di tempat ritual ditaburi beras kuning, menghidupkan dupa dan manapung tawar. 
Rangkaian kegiatan ritual adat sebagai berikut: pelaksana ritual menyiapkan 7 buah topeng. Bawayang merupakan cerita tentang pemanggilan roh yang diiringi dengan badeder (lagu-lagu untuk memanggil roh) untuk membantu proses penyembuhan dalam ritual badewah.

\section{Makna Badewah bagi Masyarakat Muslim Dayak Muara Teweh}

Tidak tampak ada perbedaan pemaknaan badewah yang prinsipil antara penduduk Muslim Muara Teweh dan tabit. Secara umum pengobatan badewah dilakukan sebagai alternatif untuk penyakit yang tak kunjung sembuh. Badewah secara sosial masih dianggap fungsional, karena dianggap cukup efektif menyembuhkan berbagai penyakit.

Hal yang tak dapat dipungkiri dalam pemilihan pengobatan badewah adalah terkait dengan penyakit personalistik. Bentuk perawatan penyakit dilakukan dengan ritual. Berdasar keyakinan yang kuat terhadap hal-hal magis, dengan perantara tabit sebagai mediator, hingga saat ini suku Dayak masih melaksanakan ritual pengobatan apabila penyakit yang diderita tidak kunjung sembuh. ${ }^{55}$

Apa saja dimensi-dimensi badewah yang mereka maknai? Dimensi tersebut mencakup aspek historis dan religiusitas pelaku badewah. Dalam konteks ini menarik untuk melihat bagaimana para pelaku badewah memaknai ritual tersebut. Pelaku badewah diklasifikasi menjadi dua, yaitu pasien dan pengobat tradisional/tabib.

a) Pengobat Tradisional/tabib

${ }^{55}$ Kadek Sukiada, Sistem Medis, 64. 
Dalam melakukan pengobatan badewah, seorang tabib juga melakukan diagnosis layaknya pengobatan modern. Sistem pengobatan badewah yang dilakukan merupakan pengetahuan yang diwarisi dari orangtuanya. H.I seorang tabib, mengaku mendapatkannya dari pengalaman pribadi ${ }^{56}$ bersama orang tua. Pengobatan badewah ini digunakan untuk mengobati berbagai penyakit. Pengobatan dengan badewah lebih banyak dikaitkan dengan pengobatan tindakan rohani. H.I diakui oleh masyarakat memiliki ilmu pengetahuan terkait dengan kebatinan, karena ketika melakukan badewah sering terbukti dapat menyembuhkan penyakit dari pasien yang datang kepadanya.

Sebagian besar pasien yang datang kepadanya termasuk dalam kategori penyakit berat, yaitu jenis penyakit yang dikategorikan tidak nyata. ${ }^{57}$ Biasanya bisa berupa penyakit tahunan yang tak kunjung sembuh, penyakit yang dianggap terkait dengan mistis, guna-guna dan ilmu hitam. Dalam pengobatan ini terdapat persyaratan khusus yang bersifat khas. ${ }^{58}$ Keyakinan terhadap kepatuhan pada persyaratan yang diajukan akan mempengaruhi proses penyembuhan. Pada saat melakukan ritual pengobatan, H.I mempunyai dua posisi sebagai tabit yaitu pada saat kegiatan batoping menjadi juru penyembuh sebagai Raden, sedangkan pada saat badewah disebut Santang.

b) Pasien Badewah

\footnotetext{
${ }^{56}$ H.I mengikuti dan melakukan ritual badewah sejak remaja yaitu tahun 1977 sampai dengan sekarang.

${ }^{57} \mathrm{Hal}$ ini nampak pada 3 pasien yang mengikuti badewah pada acara HUT kabupaten Barito Utara dimana sang tabit adalah H.I.

${ }^{58}$ Sam'ani, dkk., Urang Banjar dan Kebudayaannya (Yogyakarta: Ombak, 2015), 120.
} 
Sebagian masyarakat percaya akan keahlian seorang tabit tak lepas dari kondisi permukiman warga Suku Dayak yang jauh dari perkotaan, dan bila ada penderita suatu penyakit yang tak kunjung sembuh. Dalam ritual badewah tak hanya prosesi pengobatan semata namun terkandung sebuah ikatan sosial, ${ }^{59}$ yang menjadi perekat nilai kebersamaan diantara masyarakat Dayak. Meski secara keagamaan mereka telah menganut agama Islam, kepercayaan adat terhadap leluhur masih tetap dipegang.

Ritual penyembuhan badewah lebih menyentuh alam bawah sadar pasien dan memfokuskan pada unsur kebersamaan dan mendorong pasien secara mental. Sehingga secara psikologis baik penderita maupun keluarganya memiliki keyakinan sembuh terlebih dengan hadirnya para leluhur di sisi mereka. Ketika mereka masih duduk sebenarnya itu perjalanan untuk memanggil roh leluhur untuk datang menyembuhkan yang sakit. Pada saat menari itu para dewa diyakini telah berada bersama dalam ritual Tabit dengan gerakan tangan menggosok bahwa roh leluhur telah menyembuhkan pasien dan mengusir roh jahat atau pengaruh buruk. ${ }^{60}$

Dalam memilih sistem pengobatan yang tepat biasanya seseorang memiliki banyak pertimbangan sebelum mengambil keputusan. Contoh keluarga dari pasien pertama $(\mathrm{A})^{61}$ menceritakan alasannya memilih pengobatan badewah. Pasien sudah diajak berobat ke rumah sakit untuk

\footnotetext{
${ }^{59}$ http:// news.liputan6.com/read/113941/belian-pengobatan-tradisional, akses 25-10-

2017.

${ }^{60}$ Ibid.

${ }^{61}$ Pasien menderita gila.
} 
menjalani pengobatan, namun kondisi A tidak kunjung membaik, akhirnya mereka pulang kembali ke kampung. Maka keluarga memutuskan untuk mencoba membawa A berobat ke seorang tabit yang terkenal di Muara Teweh yang bernama H.I. Pada saat penyelenggaraan ritual badewah oleh pemerintah Barito Utara, A juga diantar oleh keuarga untuk mengikuti ritual tersebut. Setelah berobat beberapa kali, kondisi A berangsur-angsur membaik.

Pasien kedua $(B)^{62}$, dibawa berobat ke H.I, karena keluarganya mempercayai sistem pengobatan dengan cara badewah. B menderita penyakit yang sudah lama dan tahunan. Menurut keluarga B penyakit dapat disebabkan oleh banyak hal, seperti diganggu mahluk halus, guna-guna atau penyakit karena kiriman ilmu hitam. Jenis penyakit yang seperti itu tidak akan bisa diobati oleh dokter, namun dengan pengobatan mistis pula. B menceritakan pengalamannya: "Keluarga mencoba membawa saya berobat ke dokter beberapa kali dan rutin. Namun penyakit saya tidak kunjung sembuh. Melihat kondisi saya yang tidak bertambah baik, maka keluarga memutuskan untuk membawa berobat ke tabit, kemudian diadakan ritual badewah. Setelah melakukan ritual tersebut kondisi saya berangsur membaik."

Pasien ketiga (C) menderita stress yang tak kunjung sembuh. Bahkan beberapa kali ia mengamuk. Keluarganya sudah membawa berobat secara medis, namun tidak ada perubahan yang berarti. Maka keluarga $C$ memutuskan untuk membawanya berobat dengan mengikuti ritual badewah

62 Pasien menderita penyakit yang tak kunjung sembuh. 
yang dilakukan oleh H.I. Saat ini kondisi C sudah berangsur membaik. Meski pengobatan modern sudah mulai diterima oleh masyarakat Suku Dayak di pedalaman Kalimantan, namun hingga kini sistem pengobatan tradisional dan ritual badewah masih tetap bertahan.

Pandangan masyarakat bahwa seseorang akan terkena penyakit ketika terjadi keterputusan komunikasi dengan sang Pencipta, alam semesta dan sesama anggota masyarakat. Hal ini sejalan dengan sebuah penelitian tentang pengobatan tradisional di Thailand disebutkan bahwa dalam hal penyakit yang diderita seseorang harus diperhatikan sistem pengobatannya. Bahwa dalam pengobatan harus diperhatikan siklus hidup manusia. Agar selalu sehat tiga hal yang harus dijaga keseimbangannya yaitu tubuh, citta dan energi. Tubuh diartikan sebagai struktur fisik, Citta diartikan mind-heart (pikiran-hati), energi diartikan sebagai kekuatan yang menjiwai tubuh dan pikiran. Ketiganya saling terkait satu sama lain. Sebagai contoh jika salah satu anggota tubuh cedera, dalam teori ini dikatakan bahwa akan terjadi ketidakseimbangan mental (depresi atau ketakutan) dan menurukan tingkat energi.

\section{Kesimpulan}

Badewah merupakan pengobatan tradisional yang dilakukan dengan permohonan seorang hamba kepada sang pencipta untuk memeroleh kesembuhan. Dalam badewah, penanggulangan penyakit secara irasional dan yang tak kunjung sembuh lebih dominan. 
Masyarakat Muslim Muara Teweh yang melakukan badewah sebagai salah satu solusi alternatif pengobatan dan dimaknai sebagai kartu multi fungsi. Hasil fieldwork menunjukkan bahwa mayoritas pasien berasal dari penduduk lokal dan migran yang menetap di Muara Teweh. Ritual pengobatan badewah telah dimaknai secara berbeda oleh pasien. Makna itu tercermin dari tujuan dan harapan mereka dalam melakukan badewah. Suku Dayak sampai saat ini masih percaya bahwa apabila mengidap suatu penyakit sebelum atau sesudah datang ke dokter atau rumah sakit, mereka juga mencari pengobatan alternatif dengan "obat kampung" melalui tabib (dukun) suku Dayak.

\section{Daftar Rujukan}

Baal, Van J. Sejarah dan Pertumbuhan Teori Antropologi Budaya: Hingga Dekade 1970. Jakarta: Gramedia, 1988.

Darwis, dkk. Kesehatan Masyarakat dalam Perspektif Sosioantropologi. Makasar: Sah Media, 2017.

Durkheim, Emile. Sejarah Agama: The Elementary Forms of the Religious Life. terj. Inyiak Ridwan. Yogyakarta: IRCiSoD, 2003.

Florus, Paulus, dkk. Kebudayaan Dayak: Aktualisasi dan Transformasi. Jakarta: Gramedia, 1994.

http://news.liputan6.com/read/113941/belian-pengobatan-tradisional, akses 25-10-2017.

http://www.radarbanjarmasin.com/, akses 07-11-2017. 
Iper, Dunis. Mengenal Provinsi Kalimantan Tengah dari Berbagai Segi. Palangka Raya: Anugerah Indah Mandiri, 2009.

Kaelan, Metode Penelitian Agama Kualitatif Interdispliner, Yogyakarta: Paradigma, 2010.

Koentjaraningrat. Pengantar Antropologi II. Jakarta: Rineka Cipta, 2005.

Kadek Sukida. "Sistem Medis Tradisional Suku Dayak Dalam Kepercayaan Hindu Kaharingan di Kota Palangkaraya, Provinsi Kalimantan Tengah”. Jurnal Dharmasmrti, Vol. XIII, Nomor 26, Oktober 2015.

Limbeng, Julianus. "Strategi Bertahan Jaipong Lingkar Seni Budaya Bekasi. Disertasi-UI Jakarta, 2012.

M. Suriansyah Ideham, dkk (ed.). Urang Banjar dan Kebudayaannya. Yogyakarta: Ombak, 2015.

Nanik Kasniyah. "Fenomena Budaya dalam Penyembuhan Penyakit Secara Tradisional: Pijat Refleksi dan Transfer Penyakit dengan Media Binatang". Jurnal Masyarakat Kebudayaan dan Politik, No. 4, Tahun 22.

Nursyam. Madz̧bab-Madz̧ab Antropologi. Yogyakarta: LKiS, 2007.

Piyoh. "Tradisi dan Pengobatan Babore". Repository.uksw.edu/bitstream, akses 24-10-2017.

Raja Syaff. http://radhahera.blogspot.co.id/2011/, akses 09-11-2017

Rosadi, Andri. "Mencari Barokah dan Karomah: Analisis Makna Ziarah Makam di Situ Lengkong, Panjalu, Ciamis". Laporan Penelitian SCME Program Kemenag, 2012. 
Sam'ani, dkk. Urang Banjar dan Kebudayaannya. Yogyakarta: Ombak, 2015.

Suwankhong, Dusanee, Pranee Liamputtong, Bruce Lumbold. "Existing Roles of Traditional Healers (Mor Baan) in Southern Thailand". J Community Health, 2011 36: 438-445, DOI 10 1007/s10900-0119360-z.

Umbere, Musni, dkk. Sejarah Kebudayaan Kalimantan. Jakarta: Dwijaya karya, 1993.

Z. Tursunova, M. Kamp, N. Azizova \& L. Azizova. "Cultural Patterns of Health Care Beliefs and Practices among Moslem Women in Uzbekistan". Journal Health, Culture and Society, Vol. 6, No. 1, 2014, http://hcs.pitt.edu. 